\title{
Partitioning and budget of inorganic and organic chlorine species observed by MIPAS-B and TELIS in the Arctic in March 2011
}

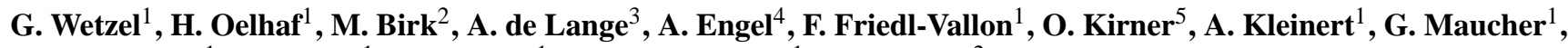 \\ H. Nordmeyer ${ }^{1}$, J. Orphal ${ }^{1}$, R. Ruhnke ${ }^{1}$, B.-M. Sinnhuber ${ }^{1}$, and P. $\operatorname{Vogt}^{2}$ \\ ${ }^{1}$ Karlsruhe Institute of Technology, Institute of Meteorology and Climate Research, Karlsruhe, Germany \\ ${ }^{2}$ Deutsches Zentrum für Luft und Raumfahrt, Institut für Methodik der Fernerkundung, Wessling, Germany \\ ${ }^{3}$ SRON-Netherlands Institute for Space Research, Utrecht, the Netherlands \\ ${ }^{4}$ Institut für Atmosphäre und Umwelt, J. W. Goethe Universität Frankfurt, Frankfurt, Germany \\ ${ }^{5}$ Karlsruhe Institute of Technology, Steinbuch Centre for Computing, Karlsruhe, Germany \\ Correspondence to: G. Wetzel (gerald.wetzel@kit.edu)
}

Received: 18 December 2014 - Published in Atmos. Chem. Phys. Discuss.: 25 February 2015

Revised: 9 July 2015 - Accepted: 10 July 2015 - Published: 22 July 2015

\begin{abstract}
The Arctic winter 2010/2011 was characterized by a persistent vortex with extremely low temperatures in the lower stratosphere above northern Scandinavia leading to a strong activation of chlorine compounds $\left(\mathrm{ClO}_{x}\right)$ like $\mathrm{Cl}, \mathrm{Cl}_{2}, \mathrm{ClO}, \mathrm{ClOOCl}, \mathrm{OClO}$, and $\mathrm{HOCl}$, which rapidly destroyed ozone when sunlight returned after winter solstice. The MIPAS-B (Michelson Interferometer for Passive Atmospheric Sounding) and TELIS (TErahertz and submillimeter LImb Sounder) balloon measurements obtained in northern Sweden on 31 March 2011 inside the polar vortex have provided vertical profiles of inorganic and organic chlorine species as well as diurnal variations of $\mathrm{ClO}$ around sunrise over the whole altitude range in which chlorine has been undergoing activation and deactivation. This flight was performed at the end of the winter during the last phase of $\mathrm{ClO}_{x}$ deactivation. The complete inorganic and organic chlorine partitioning and budget for 31 March 2011, assumed to be representative for the late-winter Arctic stratosphere, has been derived by combining MIPAS-B and TELIS simultaneously observed molecules. A total chlorine amount of $3.41 \pm 0.30$ parts per billion by volume is inferred from the measurements (above $24 \mathrm{~km}$ ). This value is in line with previous stratospheric observations carried out outside the tropics confirming the slightly decreasing chlorine amount in the stratosphere. Observations are compared and discussed with the output of a multi-year simulation performed with the chemistry climate model EMAC (ECHAM5/MESSy Atmospheric Chemistry). The simulated stratospheric total chlo-
\end{abstract}

rine amount is in accordance with the MIPAS-B/TELIS observations, taking into account the fact that some chlorine source gases and very short-lived species are not included in the model.

\section{Introduction}

The discovery of the Antarctic stratospheric "ozone hole" in the 1970s (Farman et al., 1985) strongly intensified research to unravel the reason for this ozone depletion. Chemically active chlorine $\left(\mathrm{ClO}_{x}\right)$ species like $\mathrm{Cl}, \mathrm{Cl}_{2}, \mathrm{ClO}, \mathrm{ClOOCl}$, $\mathrm{OClO}$, and $\mathrm{HOCl}$ are part of total inorganic chlorine $\mathrm{Cl}_{y}$ $\left(\mathrm{ClO}_{x}+\mathrm{HCl}+\mathrm{ClONO}_{2}\right)$. They play a dominant role in the catalytic destruction of stratospheric ozone during polar winter when low temperatures and heterogeneous chemical reactions on polar stratospheric cloud (PSC) particles have previously enabled active chlorine compounds (mainly $\mathrm{Cl}_{2}$ ) to be produced from its reservoir species $\mathrm{ClONO}_{2}, \mathrm{HCl}$, and $\mathrm{HOCl}$ (e.g. Molina and Rowland, 1974; Solomon et al., 1986; Molina et al., 1987; Solomon, 1999; Crutzen and Oppenheimer, 2008). Due to the Montreal Protocol and successive agreements, emissions of dominant halocarbons were reduced such that total tropospheric (organic) chlorine has been decreasing since 1994 after reaching a peak value of nearly 3.7 parts per billion by volume (ppbv) (O’Doherty et al., 2004; WMO, 2011). The stratospheric total chlorine peak occurred several years later, because it took this time 
for emitted air masses to propagate into the stratosphere (Engel et al., 2002; WMO, 2011; Kohlhepp et al., 2012). The amount of equivalent effective stratospheric chlorine (chlorine and bromine halogens) is predicted to return to 1980 values around 2050 at mid-latitudes (Stolarski et al., 2010; WMO, 2011).

To assess and monitor the partitioning and budget of chlorine, a number of measurements of its individual compounds have been carried out to calculate the amount of inorganic $\left(\mathrm{Cl}_{y}\right)$, organic $\left(\mathrm{CCl}_{y}\right)$, and finally total chlorine $\left(\mathrm{Cl}_{\text {total }}\right)$. An early observation based on data from the Atmospheric Trace Molecule Spectroscopy (ATMOS) instrument was published by Zander et al. (1992). A mean stratospheric total chlorine volume mixing ratio (VMR) of $2.58 \pm 0.10 \mathrm{ppbv}$ was observed at $30^{\circ} \mathrm{N}$ in 1985 . Significantly enhanced values between 3.4 and $3.5( \pm 0.4)$ ppbv in the 1992 Arctic lower stratosphere were estimated using retrieved data from the balloon-borne Michelson Interferometer for Passive Atmospheric Sounding (MIPAS-B) in combination with in situ measurements (von Clarmann et al., 1995). A further slightly enhanced value of $3.53 \pm 0.10 \mathrm{ppbv}$ was detected during the ATMOS/ATLAS-3 November 1994 mission at northern midlatitudes, also demonstrating the strong increase of stratospheric total chlorine before regulating measures could alter this linear trend of $0.10 \mathrm{ppbv}$ per year in the time period from northern spring 1985 to autumn 1994 (Zander et al., 1996). The same trend has been deduced between 1991 and 1995 by estimating total chlorine with the help of $\mathrm{HCl}$ observations from the HALogen Occultation Experiment (HALOE; Russell III et al., 1996). A further increased $\mathrm{Cl}_{\text {total }}$ value of $3.7 \pm 0.2 \mathrm{ppbv}$ was derived from MkIV balloon measurements carried out in the 1997 Arctic summer (Sen et al., 1999). This measurement took place close to the turnover of the total stratospheric chlorine amount. Chlorine data obtained by the Atmospheric Chemistry Experiment Fourier Transform Spectrometer (ACE-FTS) in combination with in situ measurements from the Stratospheric Aerosol and Gas Experiment (SAGE) III Ozone Loss and Validation Experiment (SOLVE) campaign (Schauffler et al., 2003; Nassar et al., 2006) were used to estimate $\mathrm{Cl}_{\text {total }}$ between February 2004 and January 2005 in five latitude zones. A mean stratospheric $\mathrm{Cl}_{\text {total }}$ value of $3.65 \pm 0.13 \mathrm{ppbv}$ was determined for both the northern and southern midlatitudes. This start of a temporal decrease of stratospheric chlorine was confirmed by observations from the Microwave Limb Sounder (MLS) from August 2004 until January 2006 (Froidevaux et al., 2006). A Cl total value of $3.60 \pm 0.13 \mathrm{ppbv}$ at the end of this time period was inferred from $\mathrm{HCl}$ measurements and a decrease of about 43 pptv in the stratospheric chlorine loading within this 18 -month period was detected.

The long term trend of stratospheric inorganic chlorine was investigated by using data of multiple space-borne sensors like ACE-FTS, ATMOS, MLS, CLAES (Cryogenic Limb Array Etalon Spectrometer), CRISTA (CRyogenic Infrared Spectrometer and Telescope for the Atmosphere), and
HALOE (Lary et al., 2007). This time series confirms that stratospheric $\mathrm{Cl}_{y}$ peaked in the late 1990s and started to decrease as expected due to the changing concentrations of tropospheric source gases and related transport times from the troposphere to the stratosphere. More recently published observations of $\mathrm{Cl}_{\text {total }}$ were performed by ACE-FTS covering the years 2004 until 2009. Nine chlorine containing species have been directly measured by the satellite instrument (Brown et al., 2011, 2013). These data were supplemented by a number of further trace gases calculated using the SLIMCAT 3-dimensional chemical transport model (Chipperfield, 2006). Global mean stratospheric chlorine was found to decrease by $0.46 \%$ per year in the time period under investigation.

The purpose of this paper is to assess the partitioning and budget of inorganic and organic stratospheric chlorine inside the late-winter Arctic vortex. Winter 2010/2011 was characterized by a cold vortex defining a strong transport barrier until approximately mid-April (Manney et al., 2011; Sinnhuber et al., 2011). Temperatures were below the threshold associated for chlorine activation $(\sim 196 \mathrm{~K})$ for more than 100 days between about 15 and $23 \mathrm{~km}$. Consequently, an unprecedented Arctic ozone loss was observed which could be described for the first time as an Arctic ozone hole since ozone profiles in late March resembled typical Antarctic latewinter profiles (Manney et al., 2011; Sinnhuber et al., 2011). Trace gas profiles of individual chlorine compounds were retrieved from limb-emission spectra recorded during a balloon flight of MIPAS-B and the TErahertz and submillimeter LImb Sounder (TELIS) on 31 March 2011 inside the polar vortex. A description of the instruments, data analysis, and chemical modelling is given in Sect. 2. A discussion of the observed chlorine partitioning and budget follows in Sect. 3 and in the conclusions, together with a comparison of the combined measured data to simulations of the chemistry climate model EMAC (ECHAM5/MESSy Atmospheric Chemistry model).

\section{Instruments, data analysis, and modelling}

The MIPAS-B/TELIS flight took place on 31 March 2011 over northern Scandinavia inside the Arctic vortex at the end of the chlorine deactivation period that started slowly in early March and accelerated towards the end of this month (Manney et al., 2011; Sinnhuber et al., 2011). The balloon gondola was launched from Esrange near Kiruna (Sweden, $67.9^{\circ} \mathrm{N}, 21.1^{\circ} \mathrm{E}$ ) and reached its float level at about $35 \mathrm{~km}$. Recorded limb sequences of MIPAS-B and TELIS are depicted in Fig. 1.

\subsection{MIPAS-B instrument and data analysis}

The balloon-borne limb-emission sounder MIPAS-B is a cryogenic Fourier transform spectrometer which operates in 


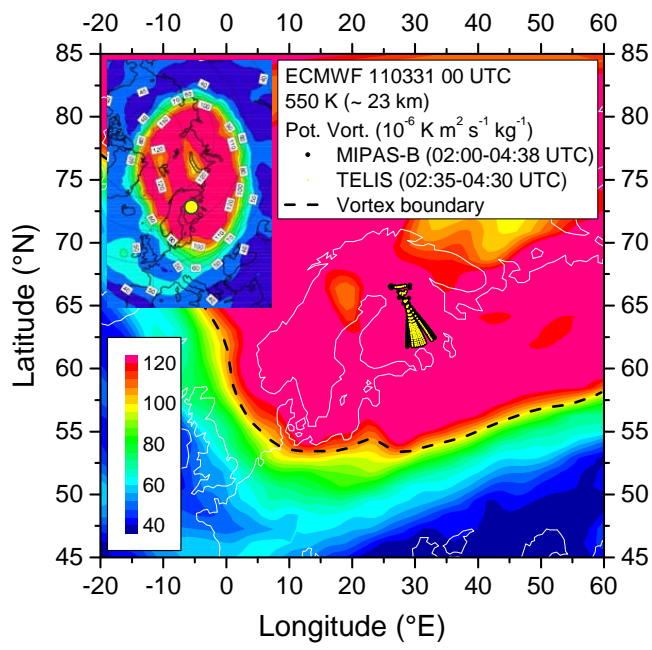

Figure 1. Potential vorticity (PV) field (in $10^{-6} \mathrm{~K} \mathrm{~m}^{2} \mathrm{~s}^{-1} \mathrm{~kg}^{-1}$ ) from European Centre for Medium-Range Weather Forecasts (ECMWF) analysis on 31 March 2011, 00:00 UTC. MIPAS-B tangent points are plotted as black solid circles and TELIS tangent points as yellow solid circles (altitude range: 9.1 to $35.4 \mathrm{~km}$ ). Both instruments look in the same direction. The vortex boundary which represents the strongest PV gradient (Nash et al., 1996) is shown as black dashed line. The insert (top left) shows the approximate measurement region (yellow marker) in relation to the position of the whole polar vortex.

the mid-infrared spectral range between about 4 and $14 \mu \mathrm{m}$. The maximum optical path difference of $14.5 \mathrm{~cm}$ of the beam in the interferometer allows a high unapodized spectral resolution of $0.0345 \mathrm{~cm}^{-1}$ (about $0.07 \mathrm{~cm}^{-1}$ after apodization with the Norton and Beer (1976) "strong" function), which allows the separation of individual spectral lines from continuum-like emissions in combination with a high radiometric accuracy of typically $1 \%$. Values of the noise equivalent spectral radiance (NESR) are typically within $1 \times 10^{-9}$ and $7 \times 10^{-9} \mathrm{~W}\left(\mathrm{~cm}^{2} \mathrm{srcm}^{-1}\right)^{-1}$ for a single calibrated spectrum. Averaging over $n$ spectra $(n \leq 5)$ per single elevation scan reduces the spectral noise by a factor of $1 / \sqrt{n}$. The instrument is characterized by a high performance and flexibility of the pointing system with a knowledge of the tangent altitude of better than $50 \mathrm{~m}$ at the $1 \sigma$ confidence limit. A comprehensive overview and description of the instrument together with processing of recorded interferograms to calibrated spectra including phase correction, Fourier Transformation to the spectral domain, and two-point calibration of the spectra from arbitrary to radiance units is given by FriedlVallon et al. (2004) and references therein. This includes instrument characterization in terms of the instrumental line shape, field of view, NESR, line of sight of the instrument, detector non-linearity (Kleinert, 2006), and the error budget of the calibrated spectra.

Forward radiance calculations were performed with the Karlsruhe Optimized and Precise Radiative transfer Algo-
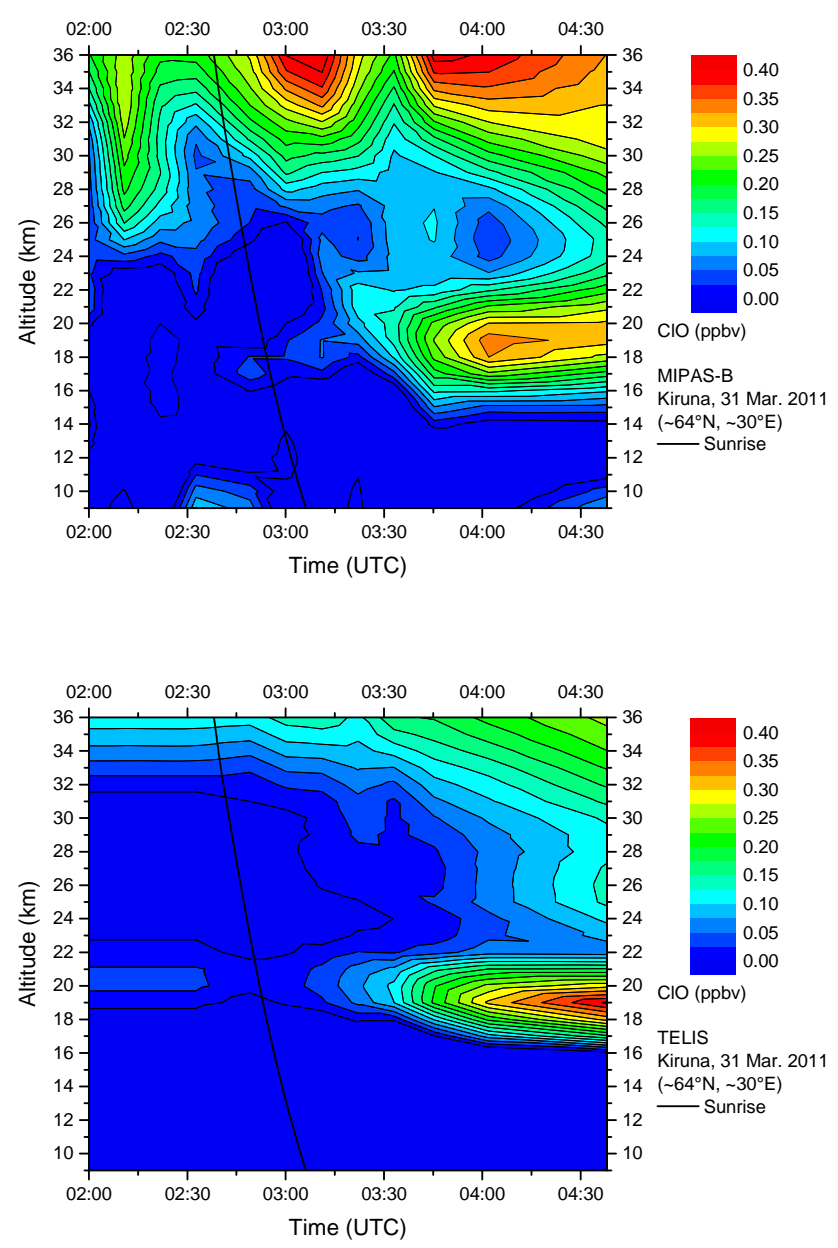

Figure 2. Temporal evolution of chlorine monoxide $(\mathrm{ClO})$ mixing ratios (ppbv) as observed by MIPAS-B (top) and TELIS (bottom) on 31 March 2011 above northern Scandinavia between 02:00 and 04:38 UTC inside the Arctic vortex within the latitude/longitude sector shown in Fig. 1. The black solid line marks the sunrise terminator. A residual activation of chlorine is visible between 16 and $22 \mathrm{~km}$ with slightly enhanced $\mathrm{ClO}$ values up to $0.4 \mathrm{ppbv}$.

rithm (KOPRA; Stiller et al., 2002), which is a line-by-line and layer-by-layer model to simulate the infrared radiative transfer through the atmosphere. Molecular spectroscopic parameters for the calculation of limb-emission spectra were taken from the high-resolution transmission molecular absorption database (HITRAN; Rothman et al., 2009) and a MIPAS dedicated spectroscopic database (Raspollini et al., 2013). KOPRA also calculates derivatives of the radiance spectrum with respect to atmospheric state and instrument parameters and thus provides the Jacobians for the retrieval procedure KOPRAFIT (Höpfner et al., 2002). Since the vertical scan distance of adjacent tangent altitudes ranges between 1 and $1.5 \mathrm{~km}$, the retrieval grid was set to $1 \mathrm{~km}$ up to the balloon float altitude. Above this level, the vertical spacing increases gradually to $10 \mathrm{~km}$ at the top altitude at $100 \mathrm{~km}$. Considering the smoothing of the vertical part of the instru- 
mental field of view, the retrieval grid is finer than the achievable vertical resolution of the measurement for a large part of the altitude region covered (especially above the observer altitude). To avoid retrieval instabilities due to this oversampling of the vertical retrieval grid, a Tikhonov-Phillips regularization approach (Phillips, 1962; Tikhonov, 1963) was applied with a constraint with respect to a first derivative of the a priori profile $\boldsymbol{x}_{\mathrm{a}}$ of the target species:

$$
\begin{aligned}
\boldsymbol{x}_{i+1} & =\boldsymbol{x}_{i}+\left[\mathbf{K}_{i}^{T} \mathbf{S}_{y}^{-1} \mathbf{K}_{i}+\mathbf{R}\right]^{-1} \\
& {\left[\mathbf{K}_{i}^{T} \mathbf{S}_{y}^{-1}\left(\boldsymbol{y}_{\text {meas }}-\boldsymbol{y}\left(\boldsymbol{x}_{i}\right)\right)-\mathbf{R}\left(\boldsymbol{x}_{i}-\boldsymbol{x}_{\mathrm{a}}\right)\right], }
\end{aligned}
$$

where $\boldsymbol{x}_{i+1}$ is the vector of the desired state parameters for iteration $i+1 ; \boldsymbol{y}_{\text {meas }}$ is the measured radiance vector and $\boldsymbol{y}\left(\boldsymbol{x}_{i}\right)$ the calculation of the radiative transfer model using state parameters of iteration number $i$; $\mathbf{K}$ is the Jacobian matrix containing partial derivatives $\partial \boldsymbol{y}\left(\boldsymbol{x}_{i}\right) / \partial \boldsymbol{x}_{i}$, while $\mathbf{S}_{y}^{-1}$ is the inverse noise measurement covariance matrix and $\mathbf{R}$ a regularization matrix with the first derivative operator and a regularization strength parameter.

In a first step, a temperature retrieval was performed using appropriate $\mathrm{CO}_{2}$ lines of two separate bands around 810 and $950 \mathrm{~cm}^{-1}$ and a priori pressure-temperature information from European Centre for Medium-Range Weather Forecasts (ECMWF) analyses together with a $\mathrm{CO}_{2}$ VMR profile updated with data from NOAA ESRL GMD (National Oceanic and Atmospheric Administration, Earth System Research Laboratory, Global Monitoring Division; Montzka et al., 1999). The temperature retrieval $1 \sigma$ accuracy is estimated to be within about $0.7 \mathrm{~K}$. Then, VMR profiles of the target species are individually retrieved in selected spectral regions (see Table 1). Profiles of species interfering with the target molecule were adjusted simultaneously during the retrieval procedure. An overview of the analysis of spectra with regard to chlorine- and nitrogen-containing molecules is given in von Clarmann et al. (1995) and Wetzel et al. (2002, 2010). The error estimation of the target parameter consists of random and systematic errors that were added in quadrature to yield the total error, which refers to the $1 \sigma$ confidence limit. Random errors include spectral noise as well as covariance effects of the simultaneously fitted parameters. Systematic errors mainly comprise spectroscopic data inaccuracies (band intensities), uncertainties in the line of sight, and gain calibration errors. The altitude resolution is calculated from the number of degrees of freedom of the retrieval, which corresponds to the trace of the averaging kernel matrix. Typical values for the retrieved parameters are given in Table 1.

Many trace gases measured by the MIPAS-B instrument have been involved in a large number of validation activities and cross-comparisons of satellite sensors like MIPAS, ILAS/ILAS-II (Improved Limb Atmospheric Spectrometer), and SMILES (Superconducting Submillimeter-Wave LimbEmission Sounder). For species used in this work we explicitly mention for evaluation the following studies: $\mathrm{ClONO}_{2}$ (Höpfner et al., 2007; Wetzel et al., 2008, 2013), CFC-11 and CFC-12 (Wetzel et al., 2008, 2013), ClO (Sagawa et al., 2013), and $\mathrm{N}_{2} \mathrm{O}$ (Wetzel et al., 2008; Payan et al., 2009).

\subsection{TELIS instrument and data analysis}

The cryogenic heterodyne balloon sounder TELIS was developed in a collaboration of three partners: the German Aerospace Centre (DLR), Rutherford Appleton Laboratory (RAL), United Kingdom, and the Netherlands Institute for Space Research (SRON). Each institute generated one channel: $1.8 \mathrm{THz}$ (DLR), $500 \mathrm{GHz}$ (RAL), and $480-650 \mathrm{GHz}$ (SRON). A comprehensive description of the instrument is given by Birk et al. (2010) and de Lange et al. (2012). The $\mathrm{HCl}$ and $\mathrm{ClO}$ results presented here were derived from spectra in the $480-650 \mathrm{GHz}$ channel with a tunable superconducting integrated receiver developed and characterized by de Lange et al. (2010, 2012). A local oscillator (LO) reference signal is mixed with the atmospheric signal in a nonlinear mixer. The measured spectrum is the superposition of two spectra covering the frequency ranges $v_{\mathrm{LO}}+v_{\mathrm{IF}}$ and $v_{\mathrm{LO}}-v_{\mathrm{IF}}$, where $v_{\mathrm{IF}}$ is the measured difference (intermediate) frequency (IF).

The analysis of the TELIS spectra is carried out in a similar way as for the MIPAS-B retrieval procedure. A forward line-by-line model is used to model the radiative transfer along the line of sight of the instrument. Spectroscopic parameters are also taken from the HITRAN database (Rothman et al., 2009). An instrument model to account for the specifics of the TELIS instrument is included in the forward algorithm. Further details on the forward model are described by de Lange et al. (2009) and references therein. The forward model is inverted with a Gauss-Newton iteration scheme in combination with a Tikhonov-Phillips regularization approach (Phillips, 1962; Tikhonov, 1963) as described in the previous section.

The $\mathrm{HCl}$ retrievals are performed for both chlorine isotopes $\mathrm{H}^{35} \mathrm{Cl}$ and $\mathrm{H}^{37} \mathrm{Cl}$. The total amount of $\mathrm{HCl}$ can be determined by taking into account the isotope abundance of $\mathrm{H}^{35} \mathrm{Cl}(75.76 \%)$ and $\mathrm{H}^{37} \mathrm{Cl}(24.23 \%)$. While the random error of $\mathrm{HCl}$ is very small $(\sim 0.01 \mathrm{ppbv})$, the systematic error estimate yields between 0.05 and $0.4 \mathrm{ppbv}$, resulting in a total error of about 10 to $15 \%$ in the region of the VMR maximum. Systematic error sources are instrumental uncertainties such as instrumental line shape and side band ratio inaccuracies, detector non-linearity, and calibration and pointing errors. Furthermore, errors in the atmospheric pressuretemperature profile as well as spectroscopic data errors are taken into account. The largest uncertainty stems from the non-linear behaviour of the detector. This holds also for the $\mathrm{ClO}$ retrievals. The overall accuracy of the $\mathrm{ClO}$ measurement is almost entirely determined by systematic error sources. Similar to $\mathrm{HCl}$, the total error for the species $\mathrm{ClO}$ typically remains within 10 and $15 \%$ in the altitude region of its VMR maximum. An overview of the characteristics of the retrieved species is given in Table 2. 
Table 1. Set-up for MIPAS-B trace species retrievals and typical $(1 \sigma)$ errors. Results are given for different state parameters in corresponding spectral windows together with the retrieval altitude resolution (Alt. reso.).

\begin{tabular}{lllll}
\hline Species & Spectral range $\left(\mathrm{cm}^{-1}\right)$ & Noise error $^{\mathrm{a}}(\%)$ & Total error $^{\mathrm{a}}(\%)$ & Alt. reso. $(\mathrm{km})$ \\
\hline $\mathrm{ClONO}_{2}$ & $779.7-780.7$ & $2-3$ & $5-6$ & $4-5$ \\
$\mathrm{ClO}$ & $821.0-841.5$ & $10-25^{\mathrm{b}}$ & $20-30^{\mathrm{b}}$ & $5-8$ \\
$\mathrm{CFC}-11$ & $840.0-860.0$ & $2-3$ & $5-6$ & $3-4$ \\
$\mathrm{CFC}-12$ & $918.0-924.0$ & $2-3$ & $5-6$ & $3-4$ \\
$\mathrm{HCFC}-22$ & $828.0-830.0$ & $3-10$ & $8-15$ & $3-6$ \\
$\mathrm{CFC}-113$ & $813.0-830.0$ & $3-10$ & $20-25$ & $3-6$ \\
$\mathrm{CCl}_{4}$ & $792.0-806.0$ & $1-5$ & $10-20$ & $4-6$ \\
$\mathrm{CH}_{3} \mathrm{Cl}$ & $742.5-755.0$ & $1-5$ & $8-15$ & $9-13$ \\
$\mathrm{HOCl}$ & $1215.0-1265.0$ & $10-15$ & $35-50$ & $6-8$ \\
$\mathrm{~N}_{2} \mathrm{O}$ & $1227.8-1303.1$ & $2-3$ & $5-6$ & $2-4$ \\
\hline
\end{tabular}

${ }^{\mathrm{a}}$ In the altitude region around the VMR maximum; ${ }^{\mathrm{b}}$ daytime errors.

Table 2. Set-up for TELIS $\mathrm{HCl}$ and $\mathrm{ClO}$ retrievals with typical $(1 \sigma)$ errors and retrieval altitude resolution (Alt. reso.).

\begin{tabular}{lllll}
\hline Species & Spectral line $(\mathrm{GHz})$ & Noise error* $(\%)$ & Total error* $(\%)$ & Alt. reso. $(\mathrm{km})$ \\
\hline $\mathrm{H}^{35} \mathrm{Cl}$ & 625.9 & $<1$ & $10-15$ & $2-5$ \\
$\mathrm{H}^{37} \mathrm{Cl}$ & 624.8 & $<1$ & $10-15$ & $2-5$ \\
$\mathrm{ClO}$ & 501.3 & $<1$ & $10-15$ & $2-4$ \\
\hline
\end{tabular}

* In the altitude region around the VMR maximum.

TELIS $\mathrm{HCl}$ and $\mathrm{ClO}$ observations have been evaluated using MLS measurements (de Lange et al., 2012). ClO was additionally compared to SMILES observations (Sagawa et al., 2013). The Sagawa study also includes a cross-comparison with MIPAS-B ClO observations.

\subsection{Model calculations}

Measured data are compared to simulations performed with the chemistry climate model EMAC, which is a numerical chemistry and climate simulation system that includes submodels describing tropospheric and middle atmosphere processes (Jöckel et al., 2010). It uses the second version of the Modular Earth Submodel System (MESSy2) to link multiinstitutional computer codes. The core atmospheric model is the fifth-generation European Centre Hamburg general circulation model (ECHAM5, Roeckner et al., 2006). For the present study we applied EMAC (ECHAM5 version 5.3.02, MESSy version 2.50) in the T42L39MA-resolution, i.e. with a spherical truncation of T42 (corresponding to a quadratic Gaussian grid of approximately $2.8^{\circ}$ by $2.8^{\circ}$ in latitude and longitude) with 39 vertical hybrid pressure levels from the ground up to $0.01 \mathrm{hPa}$. The applied model set-up comprised, among others, the submodels MECCA (Sander et al., 2005) for the calculation of gas-phase chemistry and the submodel MSBM (Kirner et al., 2011) for the simulation of polar stratospheric clouds and the calculation of heterogeneous reaction rates. The PSC scheme was validated with the help of $\mathrm{HNO}_{3}$,
$\mathrm{ClO}$, and $\mathrm{O}_{3}$ data from the MLS instrument (Kirner et al., 2015).

A Newtonian relaxation technique of the prognostic variables temperature, vorticity, divergence, and surface pressure above the boundary layer and below $1 \mathrm{hPa}$ towards the ECMWF reanalysis ERA-Interim (Dee et al., 2011) has been applied to the model to simulate realistic synoptic conditions (van Aalst, 2005). Boundary conditions for greenhouse gases, chlorofluorocarbons (CFCs), and halons are adapted from observations (WMO, 2011; Meinshausen et al., 2011). Halogenated hydrocarbons are included according to the WMO-A1 scenario (WMO, 2011). Chlorine-containing tropospheric source gases considered in EMAC are CFC-11, CFC-12, HCFC-22, CFC-113, $\mathrm{CCl}_{4}, \mathrm{CH}_{3} \mathrm{Cl}$, and $\mathrm{CH}_{3} \mathrm{CCl}_{3}$. Photolysis rates of HCFC-22 and CFC-113 are the same as for CFC-12. The simulation includes a comprehensive chemistry set-up from the troposphere to the lower mesosphere with 104 gas-phase species, 234 gas-phase reactions, 67 photolysis reactions, and 11 heterogeneous reactions on liquid aerosols, nitric acid trihydrate, and ice particles. Rate constants of gas-phase reactions are taken from Atkinson et al. (2007) and Sander et al. (2011). The model output data were saved every $10 \mathrm{~min}$. The temporally closest model output to the MIPAS-B measurements has been interpolated in space to the observed geolocations. 


\section{Chlorine partitioning and budget}

The combination of two different sensors, MIPAS-B and TELIS, working in different spectral regions (mid-infrared and microwave), enables the simultaneous measurement of virtually all relevant inorganic and organic chlorine molecules. The amount of inorganic chlorine $\left[\mathrm{Cl}_{y}\right]$ is defined as

$\left[\mathrm{Cl}_{y}\right]=\left[\mathrm{ClO}_{x}\right]+[\mathrm{HCl}]+\left[\mathrm{ClONO}_{2}\right]$,

where active chlorine $\left[\mathrm{ClO}_{x}\right]$ is calculated via

$\left[\mathrm{ClO}_{x}\right]=[\mathrm{ClO}]+[\mathrm{HOCl}]+2[\mathrm{ClOOCl}]$.

The amount of organic chlorine $\left[\mathrm{CCl}_{y}\right]$ is composed of

$$
\begin{aligned}
{\left[\mathrm{CCl}_{y}\right] } & =2[\mathrm{CFC}-12]+3[\mathrm{CFC}-11]+[\mathrm{HCFC}-22] \\
& +3[\mathrm{CFC}-113]+4\left[\mathrm{CCl}_{4}\right]+\left[\mathrm{CH}_{3} \mathrm{Cl}\right] .
\end{aligned}
$$

Total chlorine $\left[\mathrm{Cl}_{\text {total }}\right]$ is given as the sum of both budgets:

$$
\left[\mathrm{Cl}_{\text {total }}\right]=\left[\mathrm{Cl}_{y}\right]+\left[\mathrm{CCl}_{y}\right] \text {. }
$$

Constituents, which are of minor importance for the Arctic stratospheric chlorine budget (like $\mathrm{Cl}_{2}, \mathrm{Cl}, \mathrm{OClO}, \mathrm{CH}_{3} \mathrm{CCl}_{3}$, CFC-114, CFC-115, HCFC-141b, HCFC-142b, Halon-1211; see e.g. Prinn et al., 2000) are neglected here. All the quantities defined in Eqs. (2) to (5) can be deduced from TELIS (measuring $\mathrm{ClO}$ and $\mathrm{HCl}$ ) and MIPAS-B (measuring all gases except $\mathrm{HCl}$ ) observations. However, the chlorine monoxide dimer $\mathrm{ClOOCl}$ is only measurable by MIPAS$\mathrm{B}$ under activated chlorine conditions $([\mathrm{ClOOCl}]>0.5 \mathrm{ppbv})$ without any PSC emissions in the recorded spectra (Wetzel et al., 2010). On 31 March 2011, no PSC signatures are visible in the MIPAS-B spectra but $\mathrm{ClOOCl}$ concentrations are below the detection limit. However, $[\mathrm{ClOOCl}]$ can be estimated from $[\mathrm{ClO}]$ with the following relation (Wetzel et al., 2012):

$$
[\mathrm{ClOOCl}]=\left(\left[\mathrm{ClO}_{\text {noon }}\right]+2\left[\mathrm{ClOOCl}_{\text {noon }}\right]-[\mathrm{ClO}]\right) / 2,
$$

while the amounts of $\left[\mathrm{ClO}_{\text {noon }}\right]$ and $\left[\mathrm{ClOOCl}_{\text {noon }}\right]$ which correspond to noon maximum and minimum values respectively can be both taken from EMAC simulations if the modelled $\mathrm{ClO}$ is constrained to the measured one.

MIPAS-B spectra have been recorded from night until day. The sunrise took place between 02:38 UTC at $36 \mathrm{~km}$ and 03:10 UTC at $9 \mathrm{~km}$ altitude. Figure 2 shows the measured ClO cross section from 02:00 to 04:38 UTC, corresponding to $64.0^{\circ} \mathrm{N}, 30.1^{\circ} \mathrm{E}$ and $63.5^{\circ} \mathrm{N}, 28.9^{\circ} \mathrm{E}$. A temporal variation of $\mathrm{ClO}$ is visible. The concentration of this species is a measure of whether the air masses sounded are still chlorineactivated or not. After sunrise the mixing ratio of $\mathrm{ClO}$ increases in a layer between 16 and $22 \mathrm{~km}$ from nighttime values below $0.05 \mathrm{ppbv}$ to daytime mixing ratios up to $0.4 \mathrm{ppbv}$. During periods of strong chlorine activation, significantly higher values around $2 \mathrm{ppbv}$ are observed (see e.g. Santee

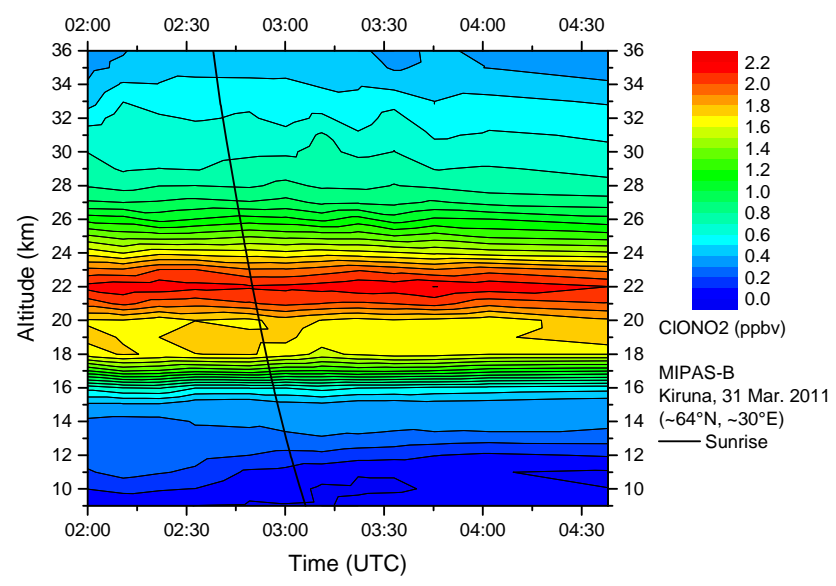

Figure 3. $\mathrm{ClONO}_{2}$ mixing ratios (ppbv) as seen by MIPAS-B above northern Scandinavia on 31 March 2011 inside the late-winter Arctic vortex. The black solid line marks the sunrise terminator.

et al., 2003; Wetzel et al., 2012). The $\mathrm{ClO}$ increase is shown by both instruments, MIPAS-B and TELIS. The latter instrument measured not only with higher vertical resolution but also with higher temporal resolution compared to MIPAS-B; hence the TELIS data were transferred to the coarser temporal grid of MIPAS-B for better comparability. At altitudes above $26 \mathrm{~km}$, MIPAS-B ClO temporal retrieval fluctuations are visible due to the large spectral noise error in this altitude region. As a consequence, the TELIS $\mathrm{ClO}$ data were used for calculating the chlorine partitioning and budget in the whole altitude range.

The decreasing $\mathrm{ClO}_{x}$ at the end of the Arctic winter in the lower stratosphere due to rising temperatures followed by shrinking $\mathrm{ClO}_{x}$ production from heterogeneous chemical reactions is in line with high amounts of $\mathrm{ClONO}_{2}$ in this altitude region. The reaction of $\mathrm{ClO}$ with $\mathrm{NO}_{2}$ produces the reservoir species $\mathrm{ClONO}_{2}$. The measured time evolution of this molecule is displayed in Fig. 3. Measured $\mathrm{ClONO}_{2}$ data exhibit high values that are typical for observations in the late Arctic winter (see e.g. Oelhaf et al., 1994; von Clarmann et al., 1997, 2009; Wetzel et al., 2002). Only in an atmospheric layer around $19 \mathrm{~km}$ is the vertical mixing ratio gradient small, since $\mathrm{ClONO}_{2}$ values (around $19 \mathrm{~km}$ ) are slightly lower than they would be if chlorine was completely deactivated. This observed signature is in line with the enhanced $\mathrm{ClO}$ amounts around $19 \mathrm{~km}$ as seen in Fig. 2. A significant diurnal temporal variation is not visible in the $\mathrm{ClONO}_{2}$ data.

The mean measured chlorine partitioning and budget for early morning is displayed in Fig. 4. A spectral noise error weighted averaging was applied to calculate the mean profiles, although statistical errors of the individual species profiles are similar. The molecules $\mathrm{ClO}$ and $\mathrm{ClOOCl}$ exhibit a temporal variation over the measured time period. However, since their mixing ratios are very low at this time in the year, vertical profiles of these species have also been av- 


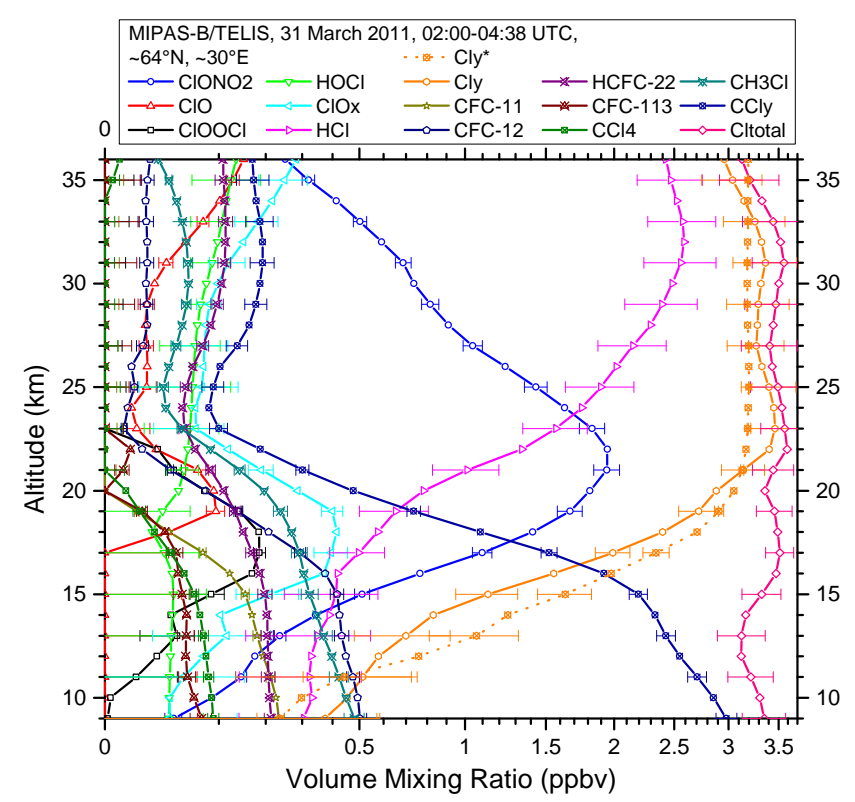

Figure 4. Partitioning and budget of inorganic, organic, and total chlorine as measured by TELIS ( $\mathrm{HCl}$ and $\mathrm{ClO}$ ) and MIPASB (all other species) in the Arctic stratosphere on 31 March 2011 (see legend for line style and note non-linear abscissa). The reservoir species $\mathrm{HCl}$ and $\mathrm{ClONO}_{2}$ dominate the stratospheric inorganic chlorine budget. $\mathrm{Cl}_{y}^{*}$ deduced from observed $\mathrm{N}_{2} \mathrm{O}$ data with the help of a $\mathrm{N}_{2} \mathrm{O}-\mathrm{Cl}_{y}$ correlation (see Eq. 7) is shown for comparison. Note that for the calculation of the chlorine budgets the atomic content for each species has to be considered (some error bars have been omitted for clarity).

eraged over the observed time period, with almost no consequence. To obtain a proxy of total inorganic chlorine, a $\mathrm{N}_{2} \mathrm{O}-$ $\mathrm{Cl}_{y}$ correlation was derived from air samples collected with the balloon-borne cryogenic whole air sampler BONBON in the Arctic between 2009 and 2011 according to the method described in Engel et al. (2002) and Wetzel et al. (2010). $\mathrm{Cl}_{y}$ from the cryosampler measurements is calculated as the difference between total chlorine and observed organic chlorine from the source gases CFC-11, CFC-12, CFC-113, $\mathrm{CH}_{3} \mathrm{CCl}_{3}, \mathrm{CCl}_{4}$, HCFC-22, HCFC-141b, and HCFC-142b. In addition, an input of $50 \mathrm{pptv}$ of chlorine from short-lived source gases is taken into account, which is assumed to be transformed immediately to inorganic chlorine. Total chlorine from the gases is propagated into the stratosphere in the same way as an inert tracer, as described in Engel et al. (2002), using global mean observation data from NOAA ESRL. The proxy inorganic chlorine $\left[\mathrm{Cl}_{y}^{*}\right]$ is calculated with the following dependence on the amount of $\left[\mathrm{N}_{2} \mathrm{O}\right]$, both given in ppbv:

$$
\begin{aligned}
{\left[\mathrm{Cl}_{y}^{*}\right] } & =3.2008346+8.7786479 \times 10^{-6}\left[\mathrm{~N}_{2} \mathrm{O}\right] \\
& -2.9132361 \times 10^{-5}\left[\mathrm{~N}_{2} \mathrm{O}\right]^{2} .
\end{aligned}
$$

This correlation has been applied to MIPAS-B measured $\mathrm{N}_{2} \mathrm{O}$ and yields up to $3.20 \mathrm{ppbv} \mathrm{Cl}_{y}^{*}$ in the stratosphere. The amount of inorganic chlorine is dominated by the chlorine reservoir species $\mathrm{ClONO}_{2}$ and $\mathrm{HCl}$, the latter one especially above $24 \mathrm{~km}$. Above this altitude, where the $\mathrm{Cl}_{y}$ VMR is (vertically) approximately constant, the mean observed $\mathrm{Cl}_{y}$ amounts to $3.25 \pm 0.30 \mathrm{ppbv}$, which is in agreement with the deduced $\mathrm{Cl}_{y}^{*}$ within the error bars although there is a tendency towards a small positive deviation in the observations compared to the $\mathrm{Cl}_{y}^{*}$ reference according to Eq. (7). The deviation between $\mathrm{Cl}_{y}$ and $\mathrm{Cl}_{y}^{*}$ below $21 \mathrm{~km}$ is caused by different degrees of subsidence of the air masses in the case of the discussed balloon flight and the $\mathrm{Cl}_{y}^{*}$ reference, which results in different $\mathrm{N}_{2} \mathrm{O}$ mixing ratios in a specific altitude. $\mathrm{Cl}_{y}$ species play by far the largest part in the total chlorine budget from the lower to the upper Arctic winter stratosphere. From about $17 \mathrm{~km}$ downwards, the amount of organic chlorine gets increasingly dominant in the total chlorine budget. Source gases that contribute to $\mathrm{CCl}_{y}$ are visible in Fig. 4: CFC-12 $\left(\mathrm{CCl}_{2} \mathrm{~F}_{2}\right), \mathrm{CFC}-11\left(\mathrm{CCl}_{3} \mathrm{~F}\right), \mathrm{HCFC}-22\left(\mathrm{CHClF}_{2}\right), \mathrm{CFC}-113$ $\left(\mathrm{C}_{2} \mathrm{Cl}_{3} \mathrm{~F}_{3}\right), \mathrm{CCl}_{4}$, and $\mathrm{CH}_{3} \mathrm{Cl}$. The mean amount of $\mathrm{Cl}_{\text {total }}$ is calculated as $3.41 \pm 0.30 \mathrm{ppbv}$ above $24 \mathrm{~km}$. From the ratio $\mathrm{Cl}_{y}$ to $\mathrm{Cl}_{\text {total }}$ it follows that about $95 \%$ of total chlorine is inorganic in this altitude region.

The mean chlorine partitioning and budget as simulated by EMAC is shown in Fig. 5. The principal vertical profile shape of the measured chlorine species is well reproduced by the model. However, some differences in detail between simulated and observed data are visible. The modelled $\mathrm{HCl}$ VMR maximum appears slightly broader than the measured one. Below about $20 \mathrm{~km}$, the simulation shows significantly lower values compared to the observation by TELIS. A difference is visible in the case of $\mathrm{ClONO}_{2}$. The model underestimates this reservoir species and deviates by $0.8 \mathrm{ppbv}$ (42\%) from the MIPAS-B data in the region of the VMR maximum at $22 \mathrm{~km}$, although simulated and measured $\mathrm{NO}_{y}$ and $\mathrm{NO}_{2}$ (a necessary reactant in the production of $\mathrm{ClONO}_{2}$ via $\mathrm{NO}_{2}$ plus $\mathrm{ClO}$ ) agree in this altitude region. Since simulated $\mathrm{HCl}$ and $\mathrm{ClO}_{x}$ (near $22 \mathrm{~km}$ ) are in agreement with the observed data, the simulated $\mathrm{Cl}_{y}$ deviation from the measurement can be attributed to the $\mathrm{ClONO}_{2}$ deficit in EMAC. Around $19 \mathrm{~km}$, the difference in simulated and measured $\mathrm{Cl}_{y}$ is largest due to very low $\mathrm{HCl}$ values in EMAC compared to the $\mathrm{HCl}$ seen by TELIS. The amount of available $\mathrm{Cl}_{y}$ below about $24 \mathrm{~km}$ is dependent on the degree of downwelling of the air masses inside the polar vortex. In EMAC, the subsidence of the air masses in the course of the winter was underestimated such that we find higher values of tracers like $\mathrm{N}_{2} \mathrm{O}$ and CFCs at a given altitude of the lower stratosphere compared to the measurements. These higher $\mathrm{N}_{2} \mathrm{O}$ values are connected with lower $\mathrm{Cl}_{y}$ values according to the compact $\mathrm{N}_{2} \mathrm{O}-\mathrm{Cl}_{y}$ relationship, resulting in an underestimation of the chlorine reservoir species (especially $\mathrm{ClONO}_{2}$ ). So, at least part of the $\mathrm{ClONO}_{2}$ deficit in EMAC can be explained by the underestimation of the subsidence in the model. 


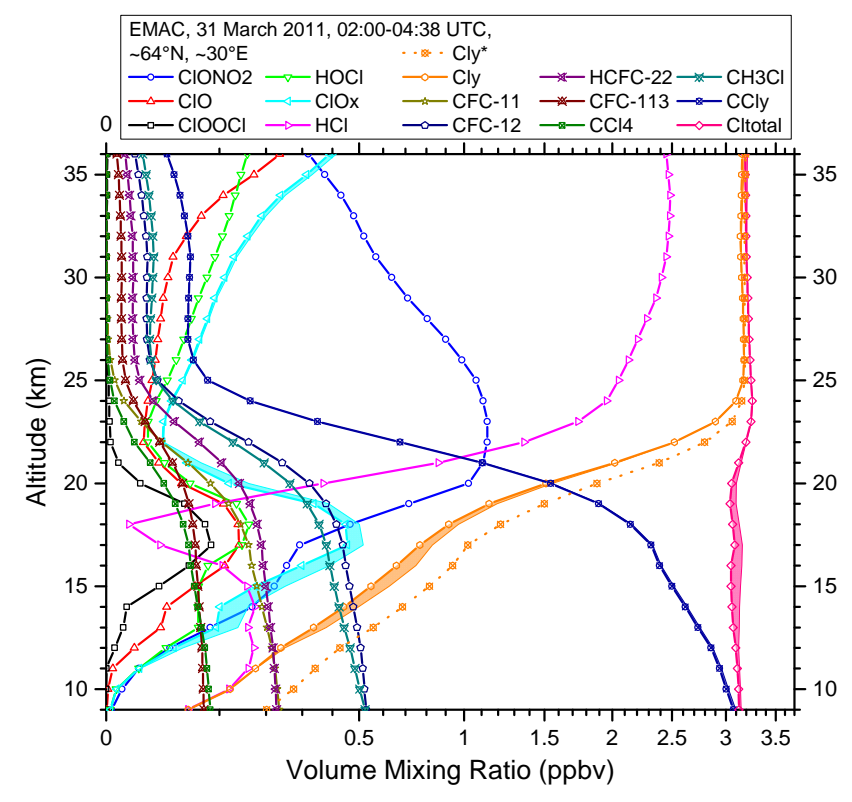

Figure 5. Partitioning and budget of inorganic, organic, and total chlorine as simulated with the chemistry climate model EMAC on 31 March 2011 (see legend for line style). $\mathrm{Cl}_{y}^{*}$ has been calculated from the simulated $\mathrm{N}_{2} \mathrm{O}$ data according to Eq. (7). The budgets $\mathrm{ClO}_{x}, \mathrm{Cl}_{y}, \mathrm{CCl}_{y}$, and $\mathrm{Cl}_{\text {total }}$ are calculated as listed in Eqs. (2) to (5) respectively. The shaded region of the budgets takes into account all minor chlorine species contained in EMAC $\left(\mathrm{Cl}_{2}, \mathrm{Cl}\right.$, $\mathrm{OClO}, \mathrm{CH}_{3} \mathrm{CCl}_{3}$ ) that were not measured by MIPAS-B and TELIS.

The simulated $\mathrm{Cl}_{y}$ reaches its maximum VMR in the quasi-altitude-constant region above $24 \mathrm{~km}$ with a mean value of $3.16 \mathrm{ppbv}$, which is slightly lower than the measured one and close to the simulated value of $\mathrm{Cl}_{y}^{*}$ (deduced from EMAC), which gives 3.19 ppbv. Below this altitude region, a similar bias between $\mathrm{Cl}_{y}$ and $\mathrm{Cl}_{y}^{*}$, as in the case of the observations, is visible.

The mean amount of $\mathrm{Cl}_{\text {total }}$ in the model run is calculated as $3.21 \mathrm{ppbv}$ above $24 \mathrm{~km}$, which is $0.20 \mathrm{ppbv}$ lower than the observed one. About half of this simulated chlorine deficit can be explained by the fact that some minor CFCs (e.g. CFC-114 and CFC-115) and HCFCs (e.g. HCFC$141 \mathrm{~b}$ and HCFC-142b) as well as halons are not included in the EMAC model. Their contribution to $\mathrm{Cl}_{\text {total }}$ is not more than $1 \%$ above $24 \mathrm{~km}$ (Brown et al., 2013). The remaining deficit can be explained by very short-lived chlorine species which altogether amount to about 0.1 ppbv (Mébarki et al., 2010; WMO, 2011) and which are also not contained in the model simulation. However, the chlorine amount of these missing species is implicitly contained in the $\mathrm{HCl}$ measurement (since the short-lived chlorine species are converted to $\mathrm{HCl}$ after being photolysed) and hence included in the observed chlorine budget. In the altitude region above $24 \mathrm{~km}$, about $98 \%$ of total chlorine in EMAC is inorganic. The shaded region of the budget profiles of $\mathrm{ClO}_{x}, \mathrm{Cl}_{y}, \mathrm{CCl}_{y}$, and $\mathrm{Cl}_{\text {total }}$ shown in Fig. 5 takes into account all available chlo- rine species in EMAC that were not measured by MIPAS-B and TELIS. These molecules comprise $\mathrm{Cl}, \mathrm{Cl}_{2}, \mathrm{OClO}$ (belonging to $\mathrm{ClO}_{x}$ and $\mathrm{Cl}_{y}$ ), and $\mathrm{CH}_{3} \mathrm{CCl}_{3}$ (belonging to $\mathrm{CCl}_{y}$ ) and add up to $0.1 \mathrm{ppbv}$ at $16 \mathrm{~km}$ to the total chlorine budget (mainly due to $\mathrm{Cl}_{2}$ and $\mathrm{OClO}$ ). However, at altitudes between 22 and $36 \mathrm{~km}$, contributions of these gases to the chlorine budget are insignificant.

\section{Conclusions}

Observations from MIPAS-B/TELIS were performed at the end of the cold 2010/2011 stratospheric winter that was characterized by a persistent polar vortex enabling strong chlorine activation and ozone loss. The chlorine partitioning measured on 31 March 2011 reveals that in the outer part of the polar vortex (above Finland) the recovery of active chlorine $\left(\mathrm{ClO}_{x}\right)$ into the reservoir species (mainly $\mathrm{ClONO}_{2}$ ) is almost completed by the end of March, only a few days before the cold period had finished (Manney et al., 2011). This is verified by low amounts of daytime $\mathrm{ClO}$ of up to $0.4 \mathrm{ppbv}$ around $19 \mathrm{~km}$. The observed total stratospheric chlorine amounts to $3.41 \pm 0.30 \mathrm{ppbv}$ above $24 \mathrm{~km}$ (see Table 3). This is in accordance with the EMAC simulation (3.21 ppbv), taking into account the fact that some chlorine source gases and very short-lived species are not included in the model. The horizontal $\mathrm{Cl}_{\text {total }}$ distribution in EMAC (above $24 \mathrm{~km}$ ) exhibits virtually no variation inside the polar vortex. The variation inside/outside vortex is no larger than $0.1 \mathrm{ppbv}$. That is smaller than the estimated $\mathrm{Cl}_{\text {total }}$ measurement accuracy of $0.3 \mathrm{ppbv}$ so that the observations can be treated as representative at least for the geographical region of the Arctic vortex. Mean $\mathrm{Cl}_{\text {total }}$ values deduced from spectra recorded by the ACE-FTS instrument (Brown et al., 2013) give $3.44 \pm 0.18 \mathrm{ppbv}$ (morning occultations) and $3.50 \pm 0.13 \mathrm{ppbv}$ (evening occultations) for northern mid-latitudes and the Arctic in 2009. Extrapolating these data to 2011 with the chlorine trend (between 2004 and 2009) obtained from these ACE-FTS observations (about $-0.4 \%$ per year) yields $\mathrm{Cl}_{\text {total }}$ values of $3.41 \mathrm{ppbv}$ (morning occultations) and $3.47 \mathrm{ppbv}$ (evening occultations) comparable to the MIPAS-B/TELIS data. The accumulated amount of minor species (not measured by MIPAS-B/TELIS) like CFC-114, CFC-115, HCFC-141b, HCFC-142b, and Halon1211 was estimated to be about $0.7 \%(\sim 0.02 \mathrm{ppbv})$ of total chlorine at $30 \mathrm{~km}$ (Brown et al., 2013). Hence, the MIPAS$\mathrm{B} /$ TELIS $\mathrm{Cl}_{\text {total }}$ value is in line with the data obtained from ACE-FTS solar occultations and is consistent with the decreasing amount of stratospheric chlorine. Considering the 2005 mean global tropospheric $\mathrm{Cl}_{\text {total }}$ from in situ data of AGAGE (Advanced Global Atmospheric Gases Experiment) and NOAA ESRL databases, as compiled in WMO (2011), and transferring this value to $30 \mathrm{~km}$, taking into account a typical time lag of 6 years of stratospheric mean age of air (Engel et al., 2002, 2009; Stiller et al., 2008; WMO, 2011), 
Table 3. Mean stratospheric chlorine budgets (ppbv, including $1 \sigma$ total errors) as measured by MIPAS-B/TELIS and simulated by EMAC in comparison to ACE-FTS observations (Brown et al., 2013) and in situ data from AGAGE and NOAA ESRL databases (WMO, 2011).

\begin{tabular}{lllll}
\hline Budget & MIPAS-B/TELIS & EMAC & ACE-FTS & In situ \\
\hline $\mathrm{Cl}_{\text {total }}$ & $3.41 \pm 0.30^{\mathrm{a}}$ & $3.21^{\mathrm{a}}$ & $3.41 / 3.47^{\mathrm{b}}$ & $3.40^{\mathrm{c}}$ \\
$\mathrm{Cl}_{y}$ & $3.25 \pm 0.30^{\mathrm{a}}$ & $3.16^{\mathrm{a}}$ & - & - \\
$\mathrm{Cl}_{y}^{*}$ & $3.19 \pm 0.002^{\mathrm{a}}$ & $3.19^{\mathrm{a}}$ & - & - \\
\hline
\end{tabular}

${ }^{\mathrm{a}}$ Mean value between 25 and $36 \mathrm{~km}$; ${ }^{\mathrm{b}}$ mean value (for morning/evening occultations) between 30 and $70^{\circ} \mathrm{N}$ for 2011 , extrapolated from 2009 with trend between 2004 and $2009 ;{ }^{\mathrm{c}}$ mean global tropospheric value from 2005 corresponding to a stratospheric value of 2011 assuming a stratospheric mean age of air of 6 years.

we get an estimated $\mathrm{Cl}_{\text {total }}$ value of $3.40 \mathrm{ppbv}$ for the year 2011, which is very close to the MIPAS-B/TELIS result (3.41 ppbv).

We finally conclude that the stratospheric total chlorine as deduced from Arctic MIPAS-B/TELIS observations on 31 March 2011 confirms previously published total chlorine assessments and their related trends. A recently published study by Mahieu et al. (2014) shows a $\mathrm{HCl}$ concentration increase between 2005/2006 and 2010/2011 in large parts of the northern hemispheric lower stratosphere in combination with an increase in the mean age of stratospheric air of up to 0.4 years. However, in the Arctic above $24 \mathrm{~km}$, ascertained changes of mean age of stratospheric air are small (Mahieu et al., 2014) and, therefore, do not alter the findings above.

Acknowledgements. The balloon flight was funded by CNRS (Centre National de la Recherche Scientifique) and CNES (Centre National d'Etudes Spatiales) within the framework of the ENRICHED (European collaboration for Research on Stratospheric Chemistry and Dynamics) project coordinated by Nathalie Huret (Laboratoire de Physique et Chimie de l'Environnement et de l'Espace (LPC2E), Orléans, France) and Hermann Oelhaf (Karlsruhe Institute of Technology (KIT), Karlsruhe, Germany). We are grateful to the CNES balloon team for excellent balloon operations and the Swedish Space Cooperation for hosting the campaign and logistical assistance. We thank Nathalie Huret for project management and modelling support and Katja Grunow from the Free University of Berlin for meteorological support. The work presented here was funded in part by the European Space Agency (ESA) and the German Aerospace Center (DLR). We acknowledge support by Deutsche Forschungsgemeinschaft and Open Access Publishing Fund of Karlsruhe Institute of Technology.

The article processing charges for this open-access publication were covered by a Research Centre of the Helmholtz Association.

Edited by: W. Lahoz

\section{References}

Atkinson, R., Baulch, D. L., Cox, R. A., Crowley, J. N., Hampson, R. F., Hynes, R. G., Jenkin, M. E., Rossi, M. J., and Troe, J.: Evaluated kinetic and photochemical data for atmospheric chemistry: Volume III - gas phase reactions of inorganic halogens, Atmos. Chem. Phys., 7, 981-1191, doi:10.5194/acp-7-981-2007, 2007.

Birk, M., Wagner, G., de Lange, G., de Lange, A., Ellison, B. N., Harman, M. R., Murk, A., Oelhaf, H., Maucher, G., and Sartorius, C.: TELIS: TErahertz and subMMW LImb Sounder Project summary after first successful flight, in: Proceedings of the 21st International Symposium on Space Terahertz Technology, University of Oxford and STFC Rutherford Appleton Laboratory, Oxford, UK, 195-200, 2010.

Brown, A. T., Chipperfield, M. P., Boone, C., Wilson, C., Walker, K. A., and Bernath, P. F.: Trends in atmospheric halogen containing gases since 2004, J. Quant. Spectrosc. Ra., 112, 2552-2566, 2011.

Brown, A. T., Chipperfield, M. P., Dhomse, S., Boone, C., and Bernath, P. F.: Global stratospheric chlorine inventories for 2004-2009 from Atmospheric Chemistry Experiment Fourier Transform Spectrometer (ACE-FTS) measurements, Atmos. Chem. Phys. Discuss., 13, 23491-23548, doi:10.5194/acpd-1323491-2013, 2013.

Chipperfield, M. P.: New Version of the TOMCAT/SLIMCAT OffLine Chemical Transport Model: Intercomparison of Stratospheric Tracer Experiments, Q. J. Roy. Meteor. Soc., 132, 11791203, 2006.

Crutzen, P. J. and Oppenheimer, M.: Learning about ozone depletion, Climatic Change, 89, 143-154, 2008.

Dee, D. P., Uppala, S. M., Simmons, A. J., Berrisford, P., Poli, P., Kobayashi, S., Andrae, U., Balmaseda, M. A., Balsamo, G., Bauer, P., Bechtold, P., Beljaars, A. C. M., van de Berg, L., Bidlot, J., Bormann, N., Delsol, C., Dragani, R., Fuentes, M., Geer, A. J., Haimberger, L., Healy, S. B., Hersbach, H., Hólm, E. V., Isaksen, L., Kållberg, P., Köhler, M., Matricardi, M., McNally, A. P., Monge-Sanz, B. M., Morcrette, J.-J., Park, B.-K., Peubey, C., deRosnay, P., Tavolato, C., Thépaut, J.-N., and Vitart, F.: The ERA-Interim reanalysis: configuration and performance of the data assimilation system, Q. J. Roy. Meteor. Soc. 137, 553-597, 2011.

de Lange, A., Landgraf, J., and Hoogeveen, R.: Stratospheric isotopic water profiles from a single submillimeter limb scan by TELIS, Atmos. Meas. Tech., 2, 423-435, doi:10.5194/amt-2423-2009, 2009.

de Lange, A., Birk, M., de Lange, G., Friedl-Vallon, F., Kiselev, O., Koshelets, V., Maucher, G., Oelhaf, H., Selig, A., Vogt, P., Wagner, G., and Landgraf, J.: $\mathrm{HCl}$ and $\mathrm{ClO}$ in activated Arctic air; first retrieved vertical profiles from TELIS submillimetre limb spectra, Atmos. Meas. Tech., 5, 487-500, doi:10.5194/amt5-487-2012, 2012.

de Lange, G., Birk, M., Boersma, D., Dercksen, J., Dmitriev, P., Ermakov, A., Filippenko, L., Golstein, H., Hoogeveen, R., de Jong, L., Khudchenko, A., Kinev, N., Kiselev, O., van Kuik, B., de Lange, A., van Rantwijk, J., Selig, A., Sobolev, A., Torgashin, M., de Vries, E., Wagner, G., Yagoubov, P., and Koshelets, V.: Development and characterization of the superconducting integrated receiver channel of the TELIS atmospheric sounder, Supercond. Sci. Tech., 23, 045016, doi:10.1088/09532048/23/4/045016, 2010. 
Engel, A., Strunk, M., Müller, M., Haase, H.-P., Poss, C., Levin, I., and Schmidt, U.: Temporal development of total chlorine in the high-latitude stratosphere based on reference distributions of mean age derived from $\mathrm{CO}_{2}$ and $\mathrm{SF}_{6}$, J. Geophys. Res., 107, 4136, doi:10.1029/2001JD000584, 2002.

Engel, A., Möbius, T., Bönisch, H., Schmidt, U., Heinz, R., Levin, I., Atlas, E., Aoki, S., Nakazawa, T., Sugawara, S., Moore, F., Hurst, D., Elkins, J., Schauffler, S., Andrews, A., and Boering, K.: Age of stratospheric air unchanged within uncertainties over the past 30 years, Nat. Geosci., 2, 28-31, 2009.

Farman, J. C., Gardiner, B. G., and Shanklin, J. D.: Large losses of total ozone in Antarctica reveal seasonal $\mathrm{ClO}_{x} / \mathrm{NO}_{x}$ interaction, Nature, 315, 207-210, 1985.

Friedl-Vallon, F., Maucher, G., Kleinert, A., Lengel, A., Keim, C., Oelhaf, H., Fischer, H., Seefeldner, M., and Trieschmann, O.: Design and characterization of the balloon-borne Michelson Interferometer for Passive Atmospheric Sounding (MIPAS-B2), Appl. Optics, 43, 3335-3355, 2004.

Froidevaux, L., Livesey, N. J., Read, W. G., Salawitch, R. J., Waters, J. W., Drouin, B., MacKenzie, I. A., Pumphrey, H. C., Bernath, P., Boone, C., Nassar, R., Montzka, S., Elkins, J., Cunnold, D., and Waugh, D.: Temporal decrease in upper atmospheric chlorine, Geophys. Res. Lett., 33, L23812, doi:10.1029/2006GL027600, 2006.

Höpfner, M., Oelhaf, H., Wetzel, G., Friedl-Vallon, F., Kleinert, A., Lengel, A., Maucher, G., Nordmeyer, H., Glatthor, N., Stiller, G., von Clarmann, T., Fischer, H., Kröger, C., and Deshler, T.: Evidence of scattering of tropospheric radiation by PSCs in mid-IR limb emission spectra: MIPAS-B observations and KOPRA simulations, Geophys. Res. Lett., 29, 1278, doi:10.1029/2001GL014443, 2002.

Höpfner, M., von Clarmann, T., Fischer, H., Funke, B., Glatthor, N., Grabowski, U., Kellmann, S., Kiefer, M., Linden, A., Milz, M., Steck, T., Stiller, G. P., Bernath, P., Blom, C. E., Blumenstock, Th., Boone, C., Chance, K., Coffey, M. T., Friedl-Vallon, F., Griffith, D., Hannigan, J. W., Hase, F., Jones, N., Jucks, K. W., Keim, C., Kleinert, A., Kouker, W., Liu, G. Y., Mahieu, E., Mellqvist, J., Mikuteit, S., Notholt, J., Oelhaf, H., Piesch, C., Reddmann, T., Ruhnke, R., Schneider, M., Strandberg, A., Toon, G., Walker, K. A., Warneke, T., Wetzel, G., Wood, S., and Zander, R.: Validation of MIPAS $\mathrm{ClONO}_{2}$ measurements, Atmos. Chem. Phys., 7, 257-281, doi:10.5194/acp-7-257-2007, 2007.

Jöckel, P., Kerkweg, A., Pozzer, A., Sander, R., Tost, H., Riede, H., Baumgaertner, A., Gromov, S., and Kern, B.: Development cycle 2 of the Modular Earth Submodel System (MESSy2), Geosci. Model Dev., 3, 717-752, doi:10.5194/gmd-3-717-2010, 2010.

Kirner, O., Ruhnke, R., Buchholz-Dietsch, J., Jöckel, P., Brühl, C., and Steil, B.: Simulation of polar stratospheric clouds in the chemistry-climate-model EMAC via the submodel PSC, Geosci. Model Dev., 4, 169-182, doi:10.5194/gmd-4-169-2011, 2011.

Kirner, O., Müller, R., Ruhnke, R., and Fischer, H.: Contribution of liquid, NAT and ice particles to chlorine activation and ozone depletion in Antarctic winter and spring, Atmos. Chem. Phys., 15, 2019-2030, doi:10.5194/acp-15-2019-2015, 2015.

Kleinert, A.: Correction of detector nonlinearity for the balloonborne Michelson Interferometer for Passive Atmospheric Sounding, Appl. Optics, 45, 425-431, 2006.

Kohlhepp, R., Ruhnke, R., Chipperfield, M. P., De Mazière, M., Notholt, J., Barthlott, S., Batchelor, R. L., Blatherwick, R. D.,
Blumenstock, Th., Coffey, M. T., Demoulin, P., Fast, H., Feng, W., Goldman, A., Griffith, D. W. T., Hamann, K., Hannigan, J. W., Hase, F., Jones, N. B., Kagawa, A., Kaiser, I., Kasai, Y., Kirner, O., Kouker, W., Lindenmaier, R., Mahieu, E., Mittermeier, R. L., Monge-Sanz, B., Morino, I., Murata, I., Nakajima, H., Palm, M., Paton-Walsh, C., Raffalski, U., Reddmann, Th., Rettinger, M., Rinsland, C. P., Rozanov, E., Schneider, M., Senten, C., Servais, C., Sinnhuber, B.-M., Smale, D., Strong, K., Sussmann, R., Taylor, J. R., Vanhaelewyn, G., Warneke, T., Whaley, C., Wiehle, M., and Wood, S. W.: Observed and simulated time evolution of $\mathrm{HCl}, \mathrm{ClONO}_{2}$, and $\mathrm{HF}$ total column abundances, Atmos. Chem. Phys., 12, 3527-3556, doi:10.5194/acp12-3527-2012, 2012.

Lary, D. J., Waugh, D. W., Douglass, A. R., Stolarski, R. S., Newman, P. A., and Mussa, H.: Variations in stratospheric inorganic chlorine between 1991 and 2006, Geophys. Res. Lett., 34, L21811, doi:10.1029/2007GL030053, 2007.

Mahieu, E., Chipperfield, M. P., Notholt, J., Reddmann, T., Anderson, J., Bernath, P. F., Blumenstock, T., Coffey, M. T., Dhomse, S. S., Feng, W., Franco, B., Froidevaux, L., Griffith, D. W. T., Hannigan, J. W., Hase, F., Hossaini, R., Jones, N. B., Morino, I., Murata, I., Nakajima, H., Palm, M., Paton-Walsh, C., Russell III, J. M., Schneider, M., Servais, C., Smale, D. and Walker, K. A.: Recent northern hemisphere stratospheric $\mathrm{HCl}$ increase due to atmospheric circulation changes, Nature, 515, 104-107, doi:10.1038/nature13857, 2014.

Manney, G. L., Santee, M. L., Rex, M., Livesey, N. J., Pitts, M. C., Veefkind, P., Nash, E. R., Wohltmann, I., Lehmann, R., Froidevaux, L., Poole, L. R., Schoeberl, M. R., Haffner, D. P., Davies, J., Dorokhov, V., Gernandt, H., Johnson, B., Kivi, R., Kyro, E., Larsen, N., Levelt, P. F., Makshtas, A., McElroy, C. T., Nakajima, H., Parrondo, M. C., Tarasick, D. W., von der Gathen, P., Walker, K. A., and Zinoviev, N. S.: Unprecedented Arctic ozone loss in 2011, Nature, 478, 469-475, doi:10.1038/nature10556, 2011.

Mébarki, Y., Catoire, V., Huret, N., Berthet, G., Robert, C., and Poulet, G.: More evidence for very short-lived substance contribution to stratospheric chlorine inferred from $\mathrm{HCl}$ balloon-borne in situ measurements in the tropics, Atmos. Chem. Phys., 10, 397-409, doi:10.5194/acp-10-397-2010, 2010.

Meinshausen, M., Smith, S. J., Calvin, K., Daniel, J. S., Kainuma, M. L. T., Lamarque, J.-F., Matsumoto, K., Montzka, S. A., Raper, S. C. B., Riahi, K., Thomson, A., Velders, G. J. M., and van Vuuren, D. P. P.: The RCP greenhouse gas concentrations and their extensions from 1765 to 2300, Climatic Change, 109, 213-241, doi:10.1007/s10584-011-0156-z, 2011.

Molina, M. J. and F. S. Rowland: Stratospheric sink for chlorofluoromethanes: chlorine atom-catalysed destruction of ozone, Nature, 249, 810-812, 1974.

Molina, M. J., Tso, T.-L., Molina, L. T., and Wang, F. C.-Y.: Antarctic stratospheric chemistry of chlorine nitrate, hydrogen chloride, and ice: Release of active chlorine, Science, 238, 1253-1257, 1987.

Montzka, S. A., Butler, J. H., Elkins, J. W., Thompson, T. M., Clarke, A. D., and Lock, L. T.: Present and future trends in the atmospheric burden of ozone-depleting halogens, Nature, 398, 690-694, 1999.

Nash, E. R., Newman, P. A., Rosenfield, J. E., and Schoeberl, M. R.: An objective determination of the polar vortex using Ertel's potential vorticity, J. Geophys. Res., 101, 9471-9478, 1996. 
Nassar, R., Bernath, P. F., Boone, C. D., Clerbaux, C., Coheur, P. F., Dufour, G., Froidevaux, L., Mahieu, E., McConnell, J. C., McLeod, S. D., Murtagh, D. P., Rinsland, C. P., Semeniuk, K., Skelton, R., Walker, K. A., and Zander, R.: A global inventory of stratospheric chlorine in 2004, J. Geophys. Res., 111, D22312, doi:10.1029/2006JD007073, 2006.

Norton, H. and Beer, R.: New apodization functions for Fourier spectroscopy, J. Opt. Soc. Am., 66, 259-264 (Errata, J. Opt. Soc. Am., 67, p. 419, 1977) 1976.

O'Doherty, S., Cunnold, D. M., Manning, A., Miller, B. R., Wang, R. H. J., Krummel, P. B., Fraser, P. J., Simmonds, P. G., McCulloch, A., Weiss, R. F., Salameh, P., Porter, L. W., Prinn, R. G., Huang, J., Sturrock, G., Ryall, D., Derwent, R. G., and Montzka, S. A.: Rapid growth of hydrofluorocarbon 134a and hydrochlorofluorocarbons 141b, 142b, and 22 from Advanced Global Atmospheric Gases Experiment (AGAGE) observations at Cape Grim, Tasmania, and Mace Head, Ireland, J. Geophys. Res., 109, D06310, doi:10.1029/2003JD004277, 2004.

Oelhaf, H., von Clarmann, T., Fischer, H., Friedl-Vallon, F., Fritsche, C., Linden, A., Piesch, C., Seefeldner, M., and Völker, W.: Stratospheric $\mathrm{ClONO}_{2}$ and $\mathrm{HNO}_{3}$ profiles inside the Arctic vortex from MIPAS-B limb emission spectra obtained during EASOE, Geophys. Res. Lett., 21, 1263-1266, 1994.

Payan, S., Camy-Peyret, C., Oelhaf, H., Wetzel, G., Maucher, G., Keim, C., Pirre, M., Huret, N., Engel, A., Volk, M. C., Kuellmann, H., Kuttippurath, J., Cortesi, U., Bianchini, G., Mencaraglia, F., Raspollini, P., Redaelli, G., Vigouroux, C., De Mazière, M., Mikuteit, S., Blumenstock, T., Velazco, V., Notholt, J., Mahieu, E., Duchatelet, P., Smale, D., Wood, S., Jones, N., Piccolo, C., Payne, V., Bracher, A., Glatthor, N., Stiller, G., Grunow, K., Jeseck, P., Te, Y., and Butz, A.: Validation of version-4.61 methane and nitrous oxide observed by MIPAS, Atmos. Chem. Phys., 9, 413-442, doi:10.5194/acp-9-413-2009, 2009.

Phillips, D.: A technique for the numerical solution of certain integral equations of the first kind, J. Assoc. Comput. Math., 9, 84-97, 1962.

Prinn, R. G., Weiss, R. F., Fraser, P. J., Simmonds, P. G., Cunnold, D. M., Alyea, F. N., O’Doherty, S., Salameh, P., Miller, B. R., Huang, J., Wang, R. H. J., Hartley, D. E., Harth, C., Steele, L. P., Sturrock, G., Midgley, P. M., and McCulloch, A.: A history of chemically and radiatively important gases in air deduced from ALE/GAGE/AGAGE, J. Geophys. Res., 105, 1775117792, 2000.

Raspollini, P., Carli, B., Carlotti, M., Ceccherini, S., Dehn, A., Dinelli, B. M., Dudhia, A., Flaud, J.-M., López-Puertas, M., Niro, F., Remedios, J. J., Ridolfi, M., Sembhi, H., Sgheri, L., and von Clarmann, T.: Ten years of MIPAS measurements with ESA Level 2 processor V6 - Part 1: Retrieval algorithm and diagnostics of the products, Atmos. Meas. Tech., 6, 2419-2439, doi:10.5194/amt-6-2419-2013, 2013.

Roeckner, E., Brokopf, R., Esch, M., Giorgetta, M., Hagemann, S., Koernblueh, L., Manzini, E., Schlese, U., and Schulzweida, U.: Sensitivity of simulated climate to horizontal and vertical resolution in the ECHAM5 atmosphere model, J. Climate, 19, 37713791, 2006.

Rothman, L. S., Gordon, I. E., Barbe, A., Benner, D. C., Bernath, P. F., Birk, M., Boudon, V., Brown, L. R., Campargue, A., Champion, J.-P., Chance, K., Coudert, L. H., Dana, V., Devi, V. M., Fally, S., Flaud, J.-M., Gamache, R. R., Goldman,
A., Jacquemart, D., Kleiner, I., Lacome, N., Lafferty, W. J., Mandin, J.-Y., Massie, S. T., Mikhailenko, S. N., Miller, C. E., Moazzen-Ahmadi, N., Naumenko, O. V., Nikitin, A. V., Orphal, J., Perevalov, V. I., Perrin, A., Predoi-Cross, A., Rinsland, C. P., Rotger, M., Šimečková, M., Smith, M. A. H., Sung, K., Tashkun, S. A., Tennyson, J., Toth, R. A., Vandaele, A. C., and Vander Auwera, J.: The HITRAN 2008 molecular spectroscopic database, J. Quant. Spectrosc. Ra., 110, 533-572, doi:10.1016/j.jqsrt.2009.02.013, 2009.

Russell III, J. M., Luo, M., Cicerone, R. J., and Deaver, L. E.: Satellite confirmation of the dominance of chlorofluorocarbons in the global stratospheric chlorine budget, Nature, 379, 526529, 1996.

Sagawa, H., Sato, T. O., Baron, P., Dupuy, E., Livesey, N., Urban, J., von Clarmann, T., de Lange, A., Wetzel, G., Connor, B. J., Kagawa, A., Murtagh, D., and Kasai, Y.: Comparison of SMILES $\mathrm{ClO}$ profiles with satellite, balloon-borne and ground-based measurements, Atmos. Meas. Tech., 6, 3325-3347, doi:10.5194/amt6-3325-2013, 2013.

Schauffler, S. M., Atlas, E. L., Donnelly, S. G., Andrews, A., Montzka, S. A., Elkins, J. W., Hurst, D. F., Romashkin, P. A., Dutton, G. S., and Stroud, V.: Chlorine budget and partitioning during the Stratospheric Aerosol and Gas Experiment (SAGE) III Ozone Loss and Validation Experiment (SOLVE), J. Geophys. Res., 108, 4173, doi:10.1029/2001JD002040, 2003.

Sander, R., Kerkweg, A., Jöckel, P., and Lelieveld, J.: Technical note: The new comprehensive atmospheric chemistry module MECCA, Atmos. Chem. Phys., 5, 445-450, doi:10.5194/acp-5445-2005, 2005

Sander, S. P., Friedl, R. R., Barker, J. R., Golden, D. M., Kurylo, M. J., Wine, P. H., Abbatt, J., Burkholder, J. B., Kolb, C. E., Moortgat, G. K., Huie, R. E., and Orkin, V. L.: Chemical kinetics and photochemical data for use in atmospheric studies Evaluation no. 17, JPL Publ. 10-6, Jet Propulsion Laboratory, Pasadena, CA, 2011.

Santee, M. L., Manney, G. L., Waters, J. W., and Livesey, N. J.: Variations and climatology of $\mathrm{ClO}$ in the polar lower stratosphere from UARS Microwave Limb Sounder measurements, J. Geophys. Res., 108, 4454, doi:10.1029/2002JD003335, 2003.

Sen, B., Osterman, G. B., Salawitch, R. J., Toon, G. C., Margitan, J. J., Blavier, J.-F., Chang, A. Y., May, R. D., Webster, C. R., Stimpfle, R. M., Bonne, G. P., Voss, P. B., Perkins, K. K., Anderson, J. G., Cohen, R. C., Elkins, J. W., Dutton, G. S., Hurst, D. F., Romashkin, P. A., Atlas, E. L., Schauffler, S. M., and Loewenstein, M.: The budget and partitioning of stratospheric chlorine during the 1997 Arctic summer, J. Geophys. Res., 104, 26653 26665, 1999.

Sinnhuber, B.-M., Stiller, G., Ruhnke, R., von Clarmann, T., Kellmann, S., and Aschmann, J.: Arctic winter 2010/2011 at the brink of an ozone hole, Geophys. Res. Lett., 38, L24814, doi:10.1029/2011GL049784, 2011.

Solomon, S.: Stratospheric ozone depletion: A review of concepts and history, Rev. Geophys., 37, 275-316, 1999.

Solomon, S., Garcia, R. R., Rowland, F. S., and Wuebbles, D. J.: On the depletion of Antarctic ozone, Nature, 321, 755-758, 1986.

Stiller, G. P., von Clarmann, T., Funke, B., Glatthor, N., Hase, F., Höpfner, M., and Linden, A.: Sensitivity of trace gas abundances retrievals from infrared limb emission spectra to simplifying ap- 
proximations in radiative transfer modeling, J. Quant. Spectrosc. Ra., 72, 249-280, 2002.

Stiller, G. P., von Clarmann, T., Höpfner, M., Glatthor, N., Grabowski, U., Kellmann, S., Kleinert, A., Linden, A., Milz, M., Reddmann, T., Steck, T., Fischer, H., Funke, B., LópezPuertas, M., and Engel, A.: Global distribution of mean age of stratospheric air from MIPAS SF 6 measurements, Atmos. Chem. Phys., 8, 677-695, doi:10.5194/acp-8-677-2008, 2008.

Stolarski, R. S., Douglass, A. R., Newman, P. A., Pawson, P., and Schoeberl, M. R.: Relative contribution of greenhouse gases and ozone-depleting substances to temperature trends in the stratosphere: A Chemistry-Climate Model study, J. Climate, 23, 2842, 2010.

Tikhonov, A.: On the solution of incorrectly stated problems and a method of regularization, Dokl. Acad. Nauk SSSR, 151, 501504, 1963.

van Aalst, M. K.: Dynamics and Transport in the Stratosphere - simulations with a general circulation model, $\mathrm{PhD}$ thesis, Institute for Marine and Atmospheric Research Utrecht, the Netherlands, 2005.

von Clarmann, T., Linden, A., Oelhaf, H., Fischer, H., FriedlVallon, F., Piesch, C., Seefeldner, M., Völker, W., Bauer, R., Engel, A., and Schmidt, U.: Determination of the stratospheric organic chlorine budget in the spring arctic vortex from MIPAS-B limb emission spectra and air sampling esperiments, J. Geophys. Res., 100, 13979-13997, 1995.

von Clarmann, T., Wetzel, G., Oelhaf, H., Friedl-Vallon, F., Linden, A., Maucher, G., Seefeldner, M., Trieschmann, O., and Lefèvre, F.: $\mathrm{ClONO}_{2}$ vertical profile and estimated mixing ratios of $\mathrm{ClO}$ and $\mathrm{HOCl}$ in winter Arctic stratosphere from Michelson interferometer for passive atmospheric sounding limb emission spectra, J. Geophys. Res., 102, 16157-16168, 1997.

von Clarmann, T., Höpfner, M., Kellmann, S., Linden, A., Chauhan, S., Funke, B., Grabowski, U., Glatthor, N., Kiefer, M., Schieferdecker, T., Stiller, G. P., and Versick, S.: Retrieval of temperature, $\mathrm{H}_{2} \mathrm{O}, \mathrm{O}_{3}, \mathrm{HNO}_{3}, \mathrm{CH}_{4}, \mathrm{~N}_{2} \mathrm{O}, \mathrm{ClONO}_{2}$ and $\mathrm{ClO}$ from MIPAS reduced resolution nominal mode limb emission measurements, Atmos. Meas. Tech., 2, 159-175, doi:10.5194/amt-2-159-2009, 2009.

Wetzel, G., Oelhaf, H., Ruhnke, R., Friedl-Vallon, F., Kleinert, A., Kouker, W., Maucher, G., Reddmann, T., Seefeldner, M., Stowasser, M., Trieschmann, O., von Clarmann, T., and Fischer, $\mathrm{H}$.: $\mathrm{NO}_{y}$ partitioning and budget and its correlation with $\mathrm{N}_{2} \mathrm{O}$ in the Arctic vortex and in summer mid-latitudes in 1997, J. Geophys. Res., 107, 4280, doi:10.1029/2001JD000916, 2002.
Wetzel, G., Sugita, T., Nakajima, H., Tanaka, T., Yokota, T., FriedlVallon, F., Kleinert, A., Maucher, G., and Oelhaf, H.: Technical Note: Intercomparison of ILAS-II version 2 and 1.4 trace species with MIPAS-B measurements, Atmos. Chem. Phys., 8, 11191126, doi:10.5194/acp-8-1119-2008, 2008.

Wetzel, G., Oelhaf, H., Kirner, O., Ruhnke, R., Friedl-Vallon, F., Kleinert, A., Maucher, G., Fischer, H., Birk, M., Wagner, G., and Engel, A.: First remote sensing measurements of $\mathrm{ClOOCl}$ along with $\mathrm{ClO}$ and $\mathrm{ClONO}_{2}$ in activated and deactivated Arctic vortex conditions using new $\mathrm{ClOOCl}$ IR absorption cross sections, Atmos. Chem. Phys., 10, 931-945, doi:10.5194/acp-10-931-2010, 2010.

Wetzel, G., Oelhaf, H., Kirner, O., Friedl-Vallon, F., Ruhnke, R., Ebersoldt, A., Kleinert, A., Maucher, G., Nordmeyer, H., and Orphal, J.: Diurnal variations of reactive chlorine and nitrogen oxides observed by MIPAS-B inside the January 2010 Arctic vortex, Atmos. Chem. Phys., 12, 6581-6592, doi:10.5194/acp12-6581-2012, 2012.

Wetzel, G., Oelhaf, H., Friedl-Vallon, F., Kleinert, A., Maucher, G., Nordmeyer, H., and Orphal, J.: Long-term intercomparison of MIPAS additional species $\mathrm{ClONO}_{2}, \mathrm{~N}_{2} \mathrm{O}_{5}$, CFC-11, and CFC12 with MIPAS-B measurements, Annal. Geophys., 56, Fast Track-1, doi:10.4401/ag-6329, 2013.

WMO (World Meteorological Organization): Scientific Assessment of Ozone Depletion: 2010, Global Ozone Research and Monitoring Project - Report No. 52, 516 pp., Geneva, Switzerland, 2011.

Zander, R., Gunson, M. R., Farmer, C. B., Rinsland, C. P., Irion, F. W., and Mahieu, E.: The 1985 chlorine and fluorine inventories in the stratosphere based on ATMOS observations at $30^{\circ}$ north latitude, J. Atmos. Chem., 15, 171-186, 1992.

Zander, R., Mahieu, E., Gunson, M. R., Abrams, M. C., Chang, A. Y., Abbas, M., Aellig, C., Engel, A., Goldman, A., Irion, F. W., Kämpfer, N., Michelsen, H. A., Newchurch, M. J., Rinsland, C. P., Salawitch, R. J., Stiller, G. P., and Toon, G. C.: The 1994 northern midlatitude budget of stratospheric chlorine derived from ATMOS/ATLAS-3 observations, Geophys. Res. Lett., 23, 2357-2360, 1996. 